\title{
An exploratory study on the potential of social enterprise to act as the institutional glue of network governance ${ }^{1}$
}

Chisung Park

Associate Professor,

College of Public Service,

Chung-Ang University,

221 Heukseok-dong, Dongjak-gu,

Seoul 156-756,

Korea.

csp711@gmail.com

Mark Wilding (Corresponding Author)

Assistant Professor,

Department of Public Administration,

Catholic University of Korea,

43 Jibong-ro, Wonmi-gu,

Bucheon, Gyeonggi-do 420-743,

Korea.

maw@catholic.ac.kr

Tel: +82-2-2164-6502

Fax: +82-2-2164-4785

1 This is an Accepted Manuscript of an article accepted for publication by Elsevier in the Social Science Journal. The latest version is available online at https://doi.org/10.1016/j.soscij.2013.08.004 


\begin{abstract}
This study combines two topics of contemporary salience for public administration; social enterprise and governance networks. While operating at different levels, both are institutions which attempt to draw together the three pillars of state, market and civil society. Still, the respective literatures tend to focus on particular aspects of the three pillars. This study attempts both to connect the two concepts and aid understanding of the potentially central role for social enterprise in governance networks. In particular, this study suggests that, in some situations, social enterprise could be conceived of as the institutional glue of networks, due to its ability to offer benefits to organizations in each of the three sectors. However, this requires social enterprises to have the managerial capacity to diffuse social know-how and to build trust, as well as a supportive policy framework. The links are explicated at the conceptual level before providing evidence from South Korea and the UK. Finally, research propositions are offered, which suggest new avenues for future research.
\end{abstract}

Keywords: Social enterprise, Governance, Networks, Collaboration 


\section{An exploratory study on the potential of social enterprise to act as the institutional glue of network governance}

\section{Introduction}

Governance networks and social enterprise have both emerged as solutions to an increasingly complex world in which governments, markets and civil society attempt to meet diverse needs. As such, both are prominent contemporary ideas in public administration research. In this study, we attempt to bring together the two different literatures in order to shed light on the role of social enterprise in local service delivery networks. In particular, we aim to explicate the role of social enterprise in cross-sectoral collaboration, and thereby contribute to a more comprehensive understanding of the role of social enterprises in governance networks.

Despite its current topical nature, social enterprise is not frequently mentioned in research on cross-sectoral governance. Similarly, most studies from the social enterprise perspective do not refer explicitly to governance networks. Some social enterprise researchers are interested in similar issues, for example Aiken (2006) analyzes the degree to which social enterprises are closer to the market or state, while Barraket (2008) argues that social enterprise can be seen to embody the network governance approach. Nevertheless, their main aim was not to engage with, nor develop links to the governance literature. This lack of cross pollination in the literature is somewhat surprising, given the recognition that social enterprises have received as important players in public service provision, and as they are known for their relationship building capacity through cross-sector partnerships with other organizations.

We make the case that social enterprise has the potential to link together a wide range of actors, or to borrow a phrase, act as the "institutional glue congealing network 
ties" (O'Toole, 1997, p. 45). This is a role that is required in order to coordinate what may have been previously disconnected actors for an effective response to complex social needs. We do not argue that social enterprise always takes on this role, rather we seek to highlight the feasibility of social enterprise as institutional glue and to draw out implications for future research. In contrast, in the extant literature there is a tendency to focus on particular aspects of collaboration, for example nonprofits and business (Austin, 2000; Kearns, 2000), nonprofits and the public sector (Goldsmith \& Eggers, 2004; Linden, 2002; Salamon, 1995), public and private sectors under public-private partnership (Bovaird, 2004), or network governance (Rhodes, 1997). Similarly, perhaps due to the lack of an agreed upon definition of social enterprise in the international context, there is a tendency in the research to focus on particular aspects of social enterprise, i.e. as a hybrid between nonprofit organizations and businesses (Dees, 1998; Dees, Emerson, \& Economy, 2001; Young, 2003; Young \& Salamon, 2002), or the provision of state services by social enterprise (Aiken \& Slater, 2007; Carmel \& Harlock, 2008; Pharoah, Scott, \& Fisher, 2004).

Within the study, the respective literatures on governance networks and social enterprise are reviewed in part two. A model for integrating the two approaches is outlined in part three, before evidence is presented from South Korea and the UK in part four. In part five, propositions are made for future investigation, and new avenues for research are suggested. Finally, a conclusion is offered in part six.

\section{Exploring governance networks and social enterprise}

\subsection{The governance approach to cross-sectoral collaboration}

As governance networks are usually regarded as coordinating mechanisms, the 
same actors can be found under the different modes of governance, albeit in differently structured relationships (O’Toole, 1997; Provan \& Kenis, 2008). While researchers usually recognize the variety of actors and relationships, there is nevertheless a tendency to focus on the spectrums outlined in Fig. 1. The network governance approach (Rhodes, 1997; Stoker, 1998) focuses more on spectrum A, public collaboration management (Agranoff, 2006; Goldsmith \& Eggers, 2004) focuses on spectrum B, and the new public management (NPM) approach (Pierre \& Peters, 2000) focuses on spectrum $\mathrm{C}$.

\section{Fig. 1 to feature here}

Taking the governance literature first, research that would be included along spectrum A includes that which discusses self-organizing policy networks, and government marginalization (Stoker, 1998). Research from the network governance perspective often considers all three pillars, however the emphasis is much more on the networks formed by business and nonprofit organizations (zones 1 and 2 of Fig. 1), most visible in the "governance without government" approach (Rhodes, 1997). In response, other authors have argued that the state continues to take a hierarchical approach (Agranoff, 2006; Bell \& Hindmoor, 2009), focusing on spectrum B.

Spectrum B includes research that focuses upon state use of nonprofit contractors. This includes the use of charities, religious organizations, and other associations. It is significant because over time these organizations have become increasingly involved in the design of services, and social services in particular. However, according to this approach, this increased involvement of civil society actors 
does not substantially undermine the hierarchical approach, as "networks threaten or hollow the boundaries of the state in only the most subtle ways" (Agranoff, 2006, p. 63). Much of the research on this spectrum focuses on zone 3 of Fig. 1, and ranges from that which stresses the increased collaboration and participation arising from state-civil society relationships, albeit with a continued role for hierarchies (Agranoff, 2006; Goldsmith \& Eggers, 2004), through to research from a more critical perspective that sees states' attempts at cutting costs and outsourcing as neo-liberalism (Phillips, 2004).

Spectrum $\mathrm{C}$ includes research on both zones 2 and 3 in Fig. 1, and ranges from hierarchical contracting arrangements (zone 3) (Bell \& Hindmoor, 2009), through to more market dominated approaches (zone 2), in areas such as climate protection for example (Benecke, Friberg, Lederer, \& Schröder, 2008). Pierre and Peters' (2000) explanation of the emergence of governance also focuses on spectrum $\mathrm{C}$, emphasizing factors such as the financial crisis of the state, the ideological shift from state to market, and the emergence of NPM. Other scholars have also made the connection between NPM and governance, for instance Jose (2007) questions whether governance is shorthand for the predominance of neo-liberalism and NPM.

From this brief overview of the governance literature, we can see that while previous research acknowledges the blurring distinctions among the public, nonprofit and business sectors, it tends to focus more on one of the spectrums, or even on one of the pillars. We think that focusing on one of the spectrums is not enough to describe the complex reality. Instead we take the position that each of these approaches is useful and can help us to understand the way that society is governed in various contexts, and understand the differing roles that social enterprise is able to play. 


\subsection{Social enterprise in relation to cross-sectoral collaboration}

There are some similarities in the social enterprise debates, as despite the existence of research that seeks to stress the cross-sectoral nature of social enterprise (Defourny, 2001; Nyssens, 2006; Ridley-Duff, 2008; Ridley-Duff \& Bull, 2011), there is a tendency within the literature to emphasize one of the spectrums. In the international context, beyond a general agreement concerning the pursuit of social goals, there is no agreed upon definition of social enterprise. As such, for the purposes of this study we use the term social enterprise to refer to "the broad idea of commercial revenue generation in the service of charitable activities" (Kerlin, 2009, p. 184). However, for the most part, social enterprise is seen as operating along spectrums A and $\mathrm{B}$, with the particular combination often depending on the national context (Defourny \& Nyssens, 2010; Kerlin, 2006, 2009).

In terms of spectrum A, US business and nonprofit scholars tend to see social enterprises as organizations that are hybrids between nonprofits and for-profits, either as a move towards the market by nonprofits or an attempt by business enterprises to engage in civil society (Dees, 1998; Dees et al., 2001; Young \& Salamon, 2002). One of the earliest attempts to define social enterprise was by Dees (1998), who sees social enterprise as a kind of social venture operating between the poles of purely philanthropic and purely commercial, i.e. along spectrum A in Fig. 1. This approach can be situated in zone 2 of Fig. 1, as it is a move towards the market in order to survive.

An alternative approach can be seen in the literature focused on countries that have traditionally had a more active state. Accordingly, there are those who focus on the provision of state services by social enterprises (zone 3 in Fig. 1) (Aiken \& Slater, 2007; Pharoah et al., 2004). Authors taking a critical perspective have commented upon the 
top-down, command and control approach from the state (Carmel \& Harlock, 2008), an approach reminiscent of Wolch (1990) and Smith and Lipsky's (1993) accounts of statenonprofit relations in the US. A consequence noted by critics of this approach is that social goals get lost along the way, as social enterprises attempt to "cream" the clients with the least complex problems in order to more easily achieve their performance targets (Aiken \& Slater, 2007). In addition, this may lead to reflexive or coercive isomorphism as organizations copy their most successful rivals or are forced to adapt their approach in order to win government contracts (Aiken \& Slater, 2007).

It is more difficult to find examples of social enterprises along spectrum C. Ridley-Duff (2008) provides examples of activities such as government promotion of private social investment in areas such as healthcare and housing. Requests from governments for businesses to establish social enterprises could also be included in this category. Social enterprises operating between the market and hierarchical modes could potentially suffer from the problems experienced by those operating in markets or hierarchies; either becoming a means to achieve profitability or losing their social goals as they attempt to meet performance targets. It can be seen however that the research on social enterprise, like that on governance, tends to focus on particular relationships among the three pillars. One explanation is that this reflects the reality in various contexts, which the authors are attempting to report and analyze.

There is however another significant body of research that highlights how some social enterprises have taken a different path. In some ways the literature focusing on stakeholder cooperatives also conceives of social enterprises as operating at the boundary between the business and nonprofit pillars (Defourny, 2001; Nyssens, 2006). Still, there are some significant differences from the organizations on spectrum A. For 
instance, priority is given to the participation of stakeholders, and ensuring that the commercial activities of these organizations directly serve their social goals, such as employment creation. Consequently, these stakeholder cooperatives are seemingly able to strike a balance between the pillars of governance. However, in reality the organizations' ability to fulfill their potential may be circumscribed by hierarchical relations and the resultant loss of autonomy (Mancino \& Thomas, 2005). Nevertheless, they represent the possibility of a more cross-sectoral form of social enterprise.

\section{Toward integration of the two: Social enterprise as institutional glue}

Thus far we have outlined how research on governance networks and social enterprise has for the most part developed in parallel. In this section we will attempt to integrate the two concepts. There are several similarities or points of overlap between governance and social enterprise. At the most fundamental level, both offer the possibility of a shift in focus from the state-market dichotomy, and both attempt to serve the needs and demands of diverse social groups. As such, both approaches could be seen as attempts to create a new synergy, and overcome the bounded rationality of older approaches. More specifically, the recent emergence of social enterprise has seen claims that the organizations can join together the diverse actors involved in governance (Barraket, 2008; Birch \& Whittam, 2008). Indeed, the roles of the respective organizations represent a good starting point. Based on the review of the literature above, governance networks can be identified as administrative mechanisms with the capability to both draw together organizations from different sectors and to work together for shared goals concerned with social needs, while social enterprise is widely seen as a hybrid form of organization. We take the perspective that it is this hybrid 
nature of social enterprise that makes it well-suited to facilitate the governance mechanism.

It may be questioned why there is a need for institutional glue in networks. This need is related to the emergence of networks themselves, which has often been in response to complex social problems. For networks to function effectively, increased interaction between previously disconnected organizations is required (Seitanidi, 2008). While previously, public administrators played a decisive role, in networks, administrators cannot be expected to retain the same degree of leverage simply on the basis of their formal position (O'Toole, 1997). Yet, while relationships may now be more horizontal in nature, this has not removed the need for coordination (Provan \& Kenis, 2008). In this study we put forward social enterprise as one candidate that may, in some situations, be able to facilitate the coordination of networks.

Since social enterprise is inherently a hybrid form of organization, it can potentially help to strengthen the ties between various actors. In this sense, social enterprise as a collaborative partner is able to add considerable value to networks and to each of the pillars. Taking collaboration with nonprofits first (spectrum 1 of Fig. 2), in practice these two institutions are similar to each other in terms of responding to social needs, but social enterprise is more market-oriented or better at business strategy than nonprofits, and can therefore be a valuable partner (Defourny, 2001). Similarly, social enterprise is potentially well situated to collaborate with businesses on corporate social responsibility (CSR) programs (spectrum 2 of Fig. 2), particularly as a fundamental motive of social enterprises is an ethical focus on cooperation or trust, and many social enterprises have experience of trading in the private sector (Evers, 2001; Tracey, Phillips, \& Haugh, 2005). Finally, working with social enterprise may also offer 
advantages to the public sector (spectrum 3 in Fig. 2), not only because of the ability of social enterprises to increase participation, but also because of their ability to ensure more efficient performance through the creation of social capital (Birch \& Whittam, 2008; Laville \& Nyssens, 2001). Moreover, as many social enterprises have multistakeholder boards they are able to bring representatives from the other institutions together in the same room and to incorporate the interests of the three pillars in a single organization (Campi, Defourny, \& Grégoire, 2006).

It is important to note that we do not suggest that social enterprise is entirely neutral or equidistant from the three pillars. In other words, a social enterprise may be influenced more by one of the sectors than the others. However, as long as social enterprises retain their inherent hybrid nature, it would not necessarily be problematic to display characteristics more closely associated with either the public, business, or nonprofit sectors. For example, social enterprises in Western Europe are generally considered to work in close proximity with the nonprofit sector, while in the USA, many are perceived to be closer to business (Kerlin, 2006). Still, although social enterprises may receive more support from government or be initiated by a business or nonprofit spirit, they remain distinct from the pure form of government, business or nonprofits.

Despite these differences among social enterprises, they retain the potential to take on the role of glue in bonding together two or three different sectors according to the issue at hand, as highlighted in Fig. 2. Two intertwining strands are key to this role; maven (Feick \& Price, 1987; Gladwell, 2000), and collaborative champion (Crosby \& Bryson, 2005). 


\section{Fig. 2 to feature here}

A maven is an expert in a particular field who passes knowledge on to others, not simply for personal gain, but because they are socially motivated (Feick \& Price, 1987; Gladwell, 2000). Acting as a maven does not instantly enable social enterprise to play the role of institutional glue, but it lays the foundation for good relations in network governance. This is because a social enterprise acting as a maven offers advice by diffusing innovative information and transferring benefits between sectors. The benefits are that simple or well-known knowledge in one sector can be innovative to another, as highlighted in recent years by the effects of business strategy on nonprofits and public organizations.

A complementary and overlapping role is that of "collaborative champion", which Crosby and Bryson (2005) see as one of the two key leadership roles in collaborative partnerships, along with that of sponsor. Collaborative champions are people who focus on collaboration and possess the coordination skills to help the network achieve its goals, while the role of sponsor is invariably played by those partners with greater access to resources, but who are not always involved in the day-today collaborative work (Crosby \& Bryson, 2005).

It is important to note that the roles of maven and collaborative champion are not mutually exclusive. Instead, the difference is more one of emphasis, and in reality, social enterprises acting as institutional glue may combine the roles in various ways. While the methods may differ depending on whether organizations primarily pass on knowledge or champion collaboration, social enterprises are able to act as institutional glue in the following ways. 
Firstly, by transferring business ideas to nonprofit or public sector organizations so as to facilitate the latter two to interact or even compete with businesses. Some public and nonprofit sector organizations are reluctant to participate in competitive markets, which are the norm in the business world. Since social enterprise is a kind of business, but does not emphasize intense competition, it can act as a buffer between business and organizations from the other two sectors.

Secondly, by working with government to encourage organizations from the other two sectors to participate in governance networks. Sometimes nonprofits and businesses are reluctant to collaborate with the public sector due to a fear of losing their independence. However, social enterprise, even when working closely with government, can be more attractive to business or nonprofit sector organizations, because dealing with social enterprises can help to reconfigure relations so that organizations no longer feel that they are operating in the shadow of the state.

Thirdly, by encouraging business and government to pursue social goals by taking a more flexible approach. Businesses and governments are relatively inactive at responding to minority social needs; sometimes social goals are marginal to businesses, and the social needs of minorities might be negligible to government. In this type of situation, social enterprise could be better than nonprofit organizations at securing the participation of businesses and governments in governance networks because social enterprises, as the name suggests, are concerned with enterprise and business, and seek the most efficient way of meeting social goals, and may even make a profit doing so.

Our motivation for highlighting the potential of social enterprise to act as 
institutional glue is to highlight how central social enterprises can be to networks, which we hope will further understanding of both social enterprise and governance networks. We do not claim that social enterprises always play this role. Rather, this model should be seen as more of an ideal type in order to draw attention to the potential of social enterprise to improve cross-sector collaboration and to encourage further discussion of the role of social enterprise in governance networks.

\section{Evidence from Korea and the UK}

In this section we aim to provide practical examples of ways in which social enterprises can be the glue of networks, through the cases of Anshim Saenghwal ("Easy Life"), a Korean social enterprise, and Social Enterprise UK (SEUK), a coalition of social enterprises, which itself also takes the social enterprise form. We selected these cases to illustrate the potential of social enterprise to act as institutional glue, as the UK and Korea are among a small number states that have enacted social enterprise legislation. Moreover, they also represent contrasting examples in that the context in which social enterprises and networks have developed differs; while the British state has undergone a shift in emphasis over the last generation from provider to purchaser, the Korean state still takes on a strong regulatory role, even though social spending has increased (Park \& Wilding, 2013). In addition, the social enterprises that we use to illustrate our argument operate at different levels. Easy Life is based in Korea's second city of Busan, while SEUK operates at the national level and focuses upon the development of social enterprise in the UK. While they may not always possess all the characteristics of the ideal type social enterprise that we have described, they nevertheless serve to illustrate the potential of social enterprise as a linking mechanism 
in governance networks.

\subsection{Korea}

The history of social enterprise in Korea is relatively short, and they have only received official recognition following the enactment of the Social Enterprise Promotion Act (SEPA) in 2007. By 2010, 501 organizations had been approved by the government as social enterprises. Government approval, given by the Ministry of Labor (ML) is necessary if organizations are to call themselves social enterprises, and also brings government subsidies, usually to support the payment of employee wages (Kwak, 2010). This financial support is given because one of the government's key roles for social enterprise is job creation, and more than half of Korean social enterprises (56.9\%) have job creation as a primary goal, while the service delivery type $(8.8 \%)$, and mixture of these two (15.8\%) make up the majority of the rest of the organizations (Kwak, 2010). Although the ML offers subsidies, and business corporations are encouraged to act as sponsors, social enterprises are still expected to raise most of their finances through sales. This view of social enterprise, as a type of organization with the potential to generate its own income, is reflected in the way that a total of 209 businesses have been recognized as social enterprises since 2007, while a significant number of nonprofits (89), and social welfare foundations (59) have also been recognized (Kwak, 2010).

While this national structure means that it is not untypical for social enterprises to have partnerships with a wide range of organizations, we have selected Easy Life, as this organization has been noted for its ability to bring together the public, business, and nonprofit sectors (Cho, 2011). Easy Life was initially established as a nonprofit organization in 2002, and was later approved as a social enterprise by the ML following 
enactment of the SEPA in 2007. The organization has grown into a large social enterprise, and it currently directly operates 10 branches, while 10 further branches are run by social franchise collaborators across Gyeongnam province. In total, around 570 people are employed, either directly or through franchises. Easy Life was founded by the current CEO, Kim Jeong Sun, who is a professor of geriatric nursing. She started Easy Life to provide visiting health and nursing services to the elderly, due to the lack of services available at that time. The organization's mission is: "to promote quality of life in the community by providing jobs to the vulnerable and/or services to elders who are socially and economically vulnerable" (Easy Life, 2013).

Easy Life's role is primarily that of a network leader or collaborative champion. This can be seen by the activities of the organization in initiating a cross-sector network and expanding relationships. In particular, Kim Jeong Sun initiated contact with a broad range of collaborative partners, including government, business, and local nonprofits (Kyunghyang Shinmun, 2009). However, this has also required the organization to take on the role of innovation diffuser/adviser, as it required the persuasive skills of Kim Jeong Sun who informed other organizations of the potential mutual benefits of collaboration (Kyunghyang Shinmun, 2009). For this work, Easy Life received the Grand Prize for Public-Private Partnership from the Ministry of Knowledge Economy in December 2010 (Easy Life, 2013). Easy Life initially gained social capital, necessary to act as institutional glue, through local community work, and was able to further develop this in the process of cross-sector strategic collaboration. In addition, the organization has been able to help develop networks through its ongoing contribution to the work of the Busan Social Enterprise Support Center, which identifies companies that are prepared to support social enterprises, as well as directly offering management and legal 
support for social enterprises (Invest Korea, 2011).

\subsubsection{Collaboration with government}

Easy Life works as a policy partner of both the ML, and Busan city government. Easy Life's relationship with the ML goes back to its approval as a social enterprise in 2007. This relationship is strategic for both organizations; the ML wants social enterprises that can create as many social jobs as possible, and in return for being an effective employment provider, Easy Life receives financial support from the ML. In particular, the ML provides the salaries for the social jobs that Easy Life creates.

In going about its work, Easy Life has also developed a relationship with Busan city government. Easy Life initiated contact with the city government, as it saw that with the support of local government, it would be better able to offer services that serve both its own interests and those of the government. Consequently, they have established a system where Easy Life receives management advice and some financial support in exchange for providing local services. On the basis of this initial collaboration, Easy life has become a policy partner of Busan city government, offering feedback and advice on the policy to expand local welfare services for the elderly in 2010 (Yonhap News, 2010). As this policy lays the groundwork for developing further collaboration between the city government and business, social enterprises and nonprofits, it is a crucial part of the architecture for future governance in the field of health and social care.

\subsubsection{Collaboration with business}

Easy Life has also initiated a partnership with the Hyundai Auto Company. This relationship involves Easy Life helping Hyundai to fulfill its CSR goals through 
providing practical know-how of social enterprise management, and assisting Hyundai to develop partnerships with other social enterprises such as "Easy Move", an organization that produces mobility-assisting equipment and other devices for people with disabilities (Hyundai, 2013). In return, Hyundai provides vehicles adapted for people with disabilities, and helps to operate job training programs, with the employees using their new skills to provide services for local government.

\subsubsection{Collaboration with nonprofits}

Since Easy Life started as a nonprofit social service delivery organization at the local level, it has been able to build close collaborative relations and exchange services with local community organizations such as public health clinics, community welfare centers, and nonprofits (Easy Life, 2013). In these relations with its service delivery partners, Easy Life has been able to diffuse information about how to make more effective public-private partnerships. Moreover, the organization has been able to develop this role and create links between social enterprise and business through its contribution to the Busan Social Enterprise Support Center.

\section{2. $U K$}

In the UK, social enterprises have taken on a variety of roles, from community development organizations to government contractors, and may now be expected to take on a bigger role in public service delivery as part of the coalition government's "Big Society", which aims to shift the emphasis in public service delivery from the government to the nonprofit sector (Scott, 2011). As such, many social enterprises have close links with local or central government. There are also strong relationships with 
businesses and nonprofit sector organizations, as many UK social enterprises have grown out of cooperatives or charities (Ridley-Duff \& Bull, 2011). Indeed, there is no strict definition of social enterprise in the UK, and a consequence of this is that there are estimated to be 68,000 social enterprises $-5.7 \%$ of all small and medium-sized enterprises (Department for Business, Innovation and Skills, 2011).

The organization that attempts to give voice to these social enterprises and act as a national body is SEUK, previously known as the Social Enterprise Coalition. SEUK was formed in 2002 by leading national social enterprises, along with high-ranking Labour politicians to attempt to bring together different types of social enterprises and the various umbrella bodies that represent them (Peattie \& Morley, 2008; Shah, 2009). The organization was conceived with the purpose of lobbying the government on behalf of social enterprises, and to capitalize on the Blair government's modernizing agenda and policy focus on competitiveness and social inclusion (Social Enterprise London, 2000). More specifically, its goals include running effective campaigns for its members, conducting research to document the size and scope of UK social enterprises, building networks, and raising the profile of social enterprises and those involved in the sector (SEUK, 2013). While many social enterprises in the UK enjoy partnerships with a broad range of partners, we selected SEUK as it has brought together particularly diverse actors, and thus is more likely to be an effective example of social enterprise as institutional glue.

As will be detailed below, SEUK's role has primarily been that of innovation diffuser/adviser. The organization has been able to fulfill this role through working with numerous partners to pass on knowledge and information, both about the potential contribution of social enterprise, and changes in government that mean new ways of 
working for social enterprises as well as businesses and nonprofits. SEUK has gained the legitimacy to play this role by being a member based organization with close links to government. This has meant that it can draw on the collective expertise of its members, and as time has progressed, the experience of working closely with government and other organizations has allowed SEUK to increase the knowledge of the organization.

\subsubsection{Collaboration with government}

SEUK has been a strategic partner to the Office for Civil Society (OCS) since the latter organization was formed in 2007 , and prior to this time, the SEUK worked closely with the Department of Trade and Industry, which previously had responsibility for social enterprises. The SEUK receives grant funding from the OCS, and in return, SEUK works with the OCS to improve the conditions for social enterprises to get off the ground and grow (SEUK, 2013). This includes a remit to help develop the social investment market and to support social enterprises in providing public services. SEUK also provides guidance and consultation for government organizations interested in engaging with social enterprises (SEUK, 2013). This has involved working with the Department of Education, the Department for Environment, Food, and Rural Affairs, Department of Health and NHS Commissioning Boards, as well as local authorities.

These activities, when viewed in combination with SEUK's lobbying and advice role in developing new policies, mean that SEUK could be seen as helping to lay the foundations for a new form of network governance. SEUK has played a significant role in developing two of the major policies of the coalition government, the Localism Act 2011, and the Public Services (Social Value)Act 2012, both of which attempt to change 
the way in which government interacts with businesses, nonprofits and social enterprises. SEUK worked as an adviser to the Department for Communities and Local Government on the Localism Act 2011 (SEUK, 2013), which among far reaching changes for local government, contains new rights for organizations including charitable trusts, social enterprises and voluntary bodies to apply to deliver services currently provided by local authorities. In addition, SEUK was awarded the Big Impact Award at the Third Sector Excellence Awards for its campaign work for the Public Services (Social Value) Act 2012 (Third Sector Excellence Awards, 2012). This act attempts to make the creation of "social value" an important procurement factor, although the extent to which it has been successful in doing so has been questioned due to the broad definition of social value (Teasdale, Alcock, \& Smith, 2012).

\subsubsection{Collaboration with business}

SEUK works with a number of mainstream businesses, including the Royal Bank of Scotland (RBS) Group, Santander, and Deloitte (SEUK, 2013). While this allows SEUK to receive financial support in exchange for helping these organizations to fulfill their CSR, it also provides opportunities to connect these businesses with other social enterprises, and crucially, to learn effective business techniques and know-how. For example, the RBS Group and Deloitte work with SEUK to support programs to develop social entrepreneurs and help them start businesses, while Santander's partnership with SEUK includes recognizing the achievements of social entrepreneurs through awards (SEUK, 2013). Many of these initiatives are concerned with building the capacity of the social sector to efficiently provide public and community services, and so these activities attempt to effectively use business knowledge to benefit both 
social enterprises and the wider public.

\subsubsection{Collaboration with nonprofits}

SEUK passes on knowledge and information to nonprofits about setting up social enterprises, as well as how to undertake the organizational transition to the social enterprise form. While this may help nonprofits to draw upon new funding sources, it also helps to meet the SEUK and OCS aim of developing the social enterprise sector's service provision capacity. SEUK is able to pass on this knowledge through the consultancy services that it provides to charities seeking ways to create more earned income. It also has charity members, which operate in the fields of care, housing, and health, among others (SEUK, 2013). With these organizations, SEUK has been pivotal in spreading the word about the new ways in which government works, and connecting social enterprises with businesses through its support programs, as well as passing on other knowledge and information acquired through experience.

\section{Implications and questions for future research}

\subsection{Lessons from the cases}

From the case analysis, it is possible to identify conditions that appear to enhance the ability of social enterprise to play the institutional glue role. This section will present three propositions that detail these conditions. Further empirical investigation of these propositions will enable researchers to determine the conditions most conducive to social enterprises coordinating governance networks.

The capability of social enterprises to play the institutional glue role appears to be related to the level of managerial capacity to (1) diffuse social know-how to other 
social enterprises, as well as businesses, nonprofits, and public agencies, and (2) maintain the trust of other organizations and communities.

Here, social know-how indicates knowledge of both how to work collaboratively with other organizations, and of how to run an organization that is neither business, nonprofit, nor public agency. A high level of trust from other organizations in the network is necessary for social enterprises to be collaborative champions or mavens, because without the trust of the other organizations, they are unlikely to be effective at transferring ideas, encouraging participation in governance networks, or in encouraging government to pursue social goals.

The extent to which social enterprises are able to play this role may also be influenced by government. Indeed, governments have played a key role in providing the legislative background for social enterprises to develop, not only through policies or laws specifically concerning social enterprises, but also those that more generally support the role of social enterprises at the center of service delivery networks. Examples of the latter include the localism and public services acts in the UK, and both local and national policies to create social jobs and expand welfare services in Korea. It is not just a one way relationship however, as social enterprises have played a role in helping governments to design these policies, as was discussed above. It is important to note however, that while structural considerations such as policy are of course important, they are not sufficient by themselves, and the agency of social enterprises is needed for them to effectively play the institutional glue role.

On the basis of the above discussion, we present the following propositions:

P1. The ability of social enterprises to act as institutional glue depends on the managerial capacity to diffuse social know-how. 
P2. The capacity of social enterprises to diffuse social know-how is facilitated by the ability to maintain the trust of other organizations in the network.

P3. The capacity of social enterprises to diffuse social know-how is facilitated by a supportive policy framework.

When the conditions outlined in the propositions are satisfied, the opportunities for social enterprises to coordinate governance networks will increase. Without social know-how, however, it would be difficult for social enterprises to play this role. Similarly, if organizations from any of the three sectors promote social enterprise, but there is a lack of agency from social enterprises themselves, then social enterprises may be open to instrumentalization.

The instrumental view includes attempts to use social enterprise to heal existing systems, and can be seen from both the market and state perspectives (Aiken \& Slater, 2007; Carmel \& Harlock, 2008; Dees, 1998; Wolch, 1990; Young, 2003). In other words, social enterprise may be used as an instrument by the public sector, nonprofits, or business in order efficiently provide services, increase income, or improve their corporate image. In situations where social enterprises are the weaker partner and are dependent upon a particular organization for their survival, they are unlikely to have the ability to act as institutional glue, as they will be required to spend their time meeting demands from the more powerful organization. We think that social enterprise is able to achieve the benefits of operating between the different pillars without becoming an instrument of government or business. However, this requires trust in social enterprise 
to act as network glue, and a supportive public policy framework.

\subsection{Further questions}

Based on the above discussion, questions have arisen, which while beyond the scope of the current study, are significant for both researchers and practitioners. While we have emphasized social enterprise's potential to act as institutional glue, the explorative nature of this study means that we have touched less on the extent to which the ideas discussed can be generalized, the disadvantages of social enterprises playing this role, and whether social enterprises are more effective than other organizations that may be able to act as institutional glue. Accordingly, we have identified the following areas for future research, which could feed into knowledge about network governance at the practical level.

1. To what extent can other social enterprises play this role?

This study has brought together the literature on governance networks and social enterprises, and has identified a key role for social enterprises that has not been explicated in previous research. However, it is less clear to what extent it is possible to generalize to other social enterprises, particularly in other national contexts. The institutional backdrop in both Korea and the UK suggests that other social enterprises in these countries may be able to play this role, as they receive policy support, may have partnership agreements with government, and are subject to interest from nonprofits and businesses. However, we do not suggest that all social enterprises in these countries can play the role of institutional glue, because some organizations may not have the same managerial capacity or strong relationships with actors from the three sectors, 
particularly if their goals do not overlap. On the other hand, research that emphasizes the multi-sectoral character of social enterprise suggests that there may be organizations in other countries that can play this role (Campi et al., 2006; Evers, 2001). Again, however, it is difficult to ascertain to what extent this is the case more generally. Further research is clearly needed, and in particular, studies that attempt to measure both the number and quality of links enjoyed by social enterprises in governance networks would be particularly valuable.

2. Are there any disadvantages to social enterprises playing this role?

In highlighting the potential of social enterprise to act as institutional glue we have focused on the positives, but there may of course also be negatives. While we have emphasized a model lying between the three pillars of governance, this does not necessarily mean that social enterprises are neutral. Indeed, social enterprises may have particular organizational, stakeholder, or community interests, and it is possible that these may clash with business, government, or nonprofits, particularly in cases where the social enterprise has a narrow focus on its own goals. More generally, there are situations where networks are best governed, not by a lead organization, but by a separate administrative organization, or where governance is shared more evenly among participants (Provan \& Kenis, 2008). One avenue for future research would be to further investigate in which situations networks would or would not benefit from social enterprises playing the institutional glue role, and to document any problems that occur along the way. 
3. Are social enterprises more effective than other organizations at playing the role of institutional glue?

While we have shown the potential of social enterprise to play the institutional glue role, this is not to suggest that other organizations cannot play this role. Indeed, previous research has highlighted how other organizations, ranging from hospitals and health centers to police departments, can be effective in coordinating networks (Hoeijmakers, Kenis, De Leeuw, \& de Vries, 2007; Weiner \& Alexander, 1998). While we speculate that organizations may be more or less effective at coordinating networks based on the situation, there is a need for research that compares networks in which different types of organizations act as mavens or collaborative champions.

\section{Conclusion}

We have, both theoretically and through the cases of social enterprise in Korea and the UK, highlighted social enterprise's potential to act as institutional glue. In addition, we have made propositions about the conditions that enhance the ability of social enterprise to take on this role. In particular, the ability of social enterprise to act as institutional glue is seemingly related to their managerial capacity to diffuse social know-how, and this capacity may be facilitated both by agency and structural factors. These factors include the ability of social enterprise to maintain the trust of other organizations, as well as a supportive policy framework. More fundamentally, we have highlighted the need to further integrate the respective literatures concerned with governance networks and social enterprise.

This study casts new light on the role of social enterprise in network governance. A benefit is that under some circumstances, social enterprises can help to facilitate 
innovative responses to social needs, greater integration of networks, and more productive partnerships. This is not to suggest that social enterprises should always play this role, or that it will have only positive effects. Our purpose is to point out the potential of social enterprise to help coordinate network responses to social needs, yet, in other situations, different organizational types may be more suited to this role.

Our approach may be criticized by those who question the originality of social enterprise and see these organizations as part of the third sector or a variation on CSR. More specifically, it could be questioned how feasible this approach is on a broad scale outside those countries which have legislated for social enterprise. Further research is needed to investigate social enterprise's capability to take on the institutional glue role in other environments, and to compare the effects of different types of organizations acting as institutional glue. Finally, the role of social enterprise in governance networks is an area that would benefit from more quantitative and representative surveys so as to clarify the extent to which social enterprise is able to act as institutional glue, and to further understand the exact nature of relationships. It is our hope that further research in this area will lead to more fruitful collaborations that further enable governance networks and social enterprises to meet social needs.

\section{References}

Agranoff, R. (2006). Inside collaborative networks: Ten lessons for public managers. Public Administration Review, 66(S1), 56-65.

Aiken, M. (2006). Towards market or state? Tensions and opportunities in the evolutionary path of three types of UK social enterprise. In M. Nyssens (Ed.), Social enterprise: At the crossroads of market, public policies and civil society 
(pp. 259-271). Routledge: London.

Aiken, M., \& Slater, R. (2007, July). Feeling the squeeze? Tabbies or tigers: The case of social enterprises contracting in the fields of recycling and work integration. Paper presented at the 4th Annual Social Enterprise Research Conference, London.

Austin, J. E. (2000). Strategic collaboration between nonprofits and businesses. Nonprofit and Voluntary Sector Quarterly, 29(1), 69-97.

Barraket, J. (2008). Social enterprise and governance: Implications for the Australian third sector. In J. Barraket (Ed.), Strategic issues for the not-for-profit sector (pp. 126-142). New South Wales: University of New South Wales Press.

Bell, S., \& Hindmoor, A. (2009). Commentary: The governance of public affairs. $J$. Public Affairs, 9(2), 149-159.

Benecke, G., Friberg, L., Lederer, M., \& Schröder, M. (2008). The clean development mechanism (CDM) as a new form of governance in climate protection, SFBGovernance Working Paper Series, No. 10. Berlin: Research Center (SFB) 700.

Birch, K., \& Whittam, G. (2008). The third sector and the regional development of social capital. Regional Studies, 42(3), 437-450.

Bovaird, T. (2004). Public-private partnerships: From contested concepts to prevalent practice. International Review of Administrative Sciences, 70(2), 199-215.

Campi, S., Defourny, J., \& Grégoire, O. (2006). Work integration social enterprises: Are they multi-stakeholder and multiple goal organizations? In M. Nyssens (Ed.), Social enterprise: At the crossroads of market, public policies and civil society (pp. 29-49). Routledge: London. 
Carmel, E., \& Harlock, J. (2008). Instituting the "third sector" as a governable terrain: Partnership, procurement and performance in the UK. Policy \& Politics, 36(2), $155-171$.

Cho, Y. B. (2011). Social enterprise, beautiful managerial story. Seoul: Sigma Press (in Korean).

Crosby, B. C., \& Bryson, J. M. (2005). Leadership for the common good: Tackling public problems in a shared-power world (2nd ed.). San Francisco, CA: Jossey Bass.

Dees, J. G. (1998). Enterprising nonprofits. Harvard Business Review, 76, 55-67.

Dees, J. G., Emerson, J., \& Economy, P. (2001). Enterprising nonprofits: A toolkit for social entrepreneurs. New York, NY: Wiley.

Defourny, J. (2001). Introduction. In C. Borzaga, \& J. Defourny (Eds.), The emergence of social enterprise (pp.1-28). London: Routledge.

Defourny, J., \& Nyssens, M. (2010). Conceptions of social enterprise and social entrepreneurship in Europe and the United States: Convergences and divergences. Journal of Social Entrepreneurship, 1(1), 32-53.

Department for Business, Innovation and Skills (BIS). (2011). BIS small business survey 2010. London: BIS.

Easy Life. (2013). Easy Life homepage. Retrieved from http://www.ansim.org/index.asp

Evers, A. (2001). The significance of social capital in the multiple goal and resource structure of social enterprises. In C. Borzaga, \& J. Defourny (Eds.), The emergence of social enterprise (pp. 296-311). London: Routledge.

Feick, L. F., \& Price, L. L. (1987). The market maven: A diffuser of marketplace information. Journal of Marketing, 51(1), 83-97. 
Gladwell, M. (2000). The tipping point: How little things can make a big difference. New York, NY: Little, Brown \& Co.

Goldsmith, S., \& Eggers, W. D. (2004). Governing by network: The new shape of the public sector. Washington DC: Brookings Institution.

Hoeijmakers, M., Kenis, P., De Leeuw, E., \& de Vries, N. K. (2007). Local health policy development processes - an expanded toolbox. Health Promotion International, 22(2), 112-21.

Hyundai. (2013). Hope campaign: Social enterprise. Retrieved from http://www.hyundaimotorgroup.com/hmg/web/eng/csr/scl/Socialcompany01.do Invest Korea. (2011, October 10). Busan social enterprise center opened. Retrieved from http://www.investkorea.org/ikwork/reg/eng/ne/index.jsp?1_unit=90202\&m_unit $=90301 \&$ code $=1060401 \&$ no $=608300004 \&$ page $=8 \&$ bno $=110100048 \&$ seq $=283$

Jose J. (2007). Reframing the governance story. Australian Journal of Political Science, $42(3), 455-470$.

Kearns, K. P. (2000). Private sector strategies for social sector success: The guide to strategy and planning for public and nonprofit organizations. San Francisco, CA: Jossey-Bass.

Kerlin, J. A. (2006). Social enterprise in the United States and Europe: Understanding and learning from the differences. Voluntas, 17(3), 246-262.

Kerlin, J. A. (2009). A comparison of social enterprise models and contexts. In J. A. Kerlin (Ed.), Social enterprise: A global comparison (pp. 184-200). Lebanon, NH: Tuft University Press. 
Kwak, S. H. (2010). An analysis of accomplishments on the third anniversary of social enterprises. Seoul: Ministry of Employment and Labor (in Korean).

Kyunghyang Shinmun. (2009, August 17). Supply outstripped by demand in domestic elderly welfare services (in Korean). Retrieved from http://news.khan.co.kr/kh_news/khan_art_view.html?artid=200908161726525\& code $=210000$

Laville, J. L., \& Nyssens, M. (2001). Towards a theoretical socio-economic approach. In C. Borzaga \& J. Defourny (Eds.), The emergence of social enterprise (pp. 312-332). London: Routledge.

Linden, R. M. (2002). Working across boundaries: Making collaboration work in government and nonprofit organizations. San Francisco, CA: Jossey-Bass.

Mancino, A., \& Thomas, A. (2005). An Italian pattern of social enterprise: The social cooperative. Nonprofit Management \& Leadership, 15(3), 357-369.

Nyssens, M. (2006). Social enterprise: At the crossroads of market, public policies and civil society. In M. Nyssens (Ed.), Social enterprise: At the crossroads of market, public policies and civil society (pp. 313-328). London: Routledge.

O’Toole, L. J., (1997). Treating networks seriously: Practical and research-based agendas in public administration. Public Administration Review, 57(1), 45-52.

Park, C., and Wilding, M. (2013). Social enterprise policy design: Constructing social enterprise in the UK and Korea. International Journal of Social Welfare, 22(3), 236-247.

Peattie, K., \& Morley, A. (2008). Social enterprises: Diversity and dynamics, contexts and contributions. London: Social Enterprise Coalition. 
Pharoah, C., Scott, D., \& Fisher, A. (2004). Social enterprise in the balance:

Challenges for the voluntary sector. West Malling: Charities Aid Foundation. Phillips, R. (2004, July). Challenges to NGOs' legitimacy in policy governance in Australia: Addressing the neo-liberal critique. Paper presented at the ISTR Sixth International Conference, Toronto.

Pierre, J., \& Peters, B. G. (2000). Governance, politics and the state. Basingstoke: Macmillan.

Provan K. G., \& Kenis, P. (2008). Modes of network governance: Structure, management, and effectiveness. J Public Adm Res Theory, 18(2), 229-252.

Rhodes, R. A. W. (1997). Understanding governance: Policy networks, governance, reflexibility and accountability. Buckingham: Open University Press.

Ridley-Duff, R. (2008). Social enterprise as a socially rational business. International Journal of Entrepreneurial Behaviour \& Research, 14(5), 291-312.

Ridley-Duff, R., \& Bull, M. (2011). Understanding social enterprise: Theory \& practice. London: Sage.

Salamon, L. M. (1995). Partners in public service: Government-nonprofit relations in the modern welfare state. London: The Johns Hopkins University Press.

Scott, M. (2011). Reflections on "the Big Society". Community Development Journal, $48(1), 132-137$.

Seitanidi, M. M. (2008). Nonlinear interactions in cross sector social partnerships. Emergence: Complexity \& Organization, 10(3), 51-64.

Shah, D. (2009). A UK policy perspective: Thought piece from the UK Social Enterprise Coalition. Social Enterprise Journal, 5(2), 104-113. 
Smith, S. R., \& Lipsky, M. (1993). Nonprofits for hire: The welfare state in the age of contracting. Cambridge, MA: Harvard University Press.

Social Enterprise London. (2000). Social enterprise in a regional context: Main findings from a study visit to Valencia, Spain. London: Social Enterprise London.

Social Enterprise UK. (2013). Social Enterprise UK homepage. Retrieved from http://www.socialenterprise.org.uk/

Stoker, G. (1998). Governance as theory: Five propositions. International Social Science Journal, 50, 17-28.

Teasdale, S., Alcock, P., \& Smith, G. (2012). Legislating for the Big Society? The case of the Public Services (Social Enterprise and Social Value) Bill. Public Money \& Management, 32(3), 201-208.

Third Sector Excellence Awards. (2012). Winners 2012. Retrieved from http://www.thirdsectorexcellenceawards.com/Winners\%202012

Tracey, P., Phillips, N., \& Haugh, H. (2005). Beyond philanthropy: Community enterprise as a basis for corporate citizenship. Journal of Business Ethics, 58(4), 327-344.

Weiner, B. J., \& Alexander, J. A. (1998). The challenges of governing public-private community health partnerships. Health Care Management Review, 23(2), 39-55.

Wolch, J. R. (1990). The shadow state: Government and voluntary sector in transition. New York, NY: Foundation Center.

Yonhap News. (2010, September 9). Busan city welfare for the elderly to be greatly expanded from 2014 (in Korean). Retrieved from http://www.yonhapnews.co.kr/local/2010/09/08/0802000000AKR20100908197 900051.HTML 
Young, D. R. (2003). New trends in the US non-profit sector: Towards market integration? In OECD (Ed.), The non-profit sector in a changing economy (pp. 61-77). Paris: OECD.

Young, D. R., \& Salamon, L. M. (2002). Commercialization, social ventures, and forprofit competition. In L. M. Salamon (Ed.), The state of non-profit America (pp. 425-448). Washington, DC: Brookings Institution. 


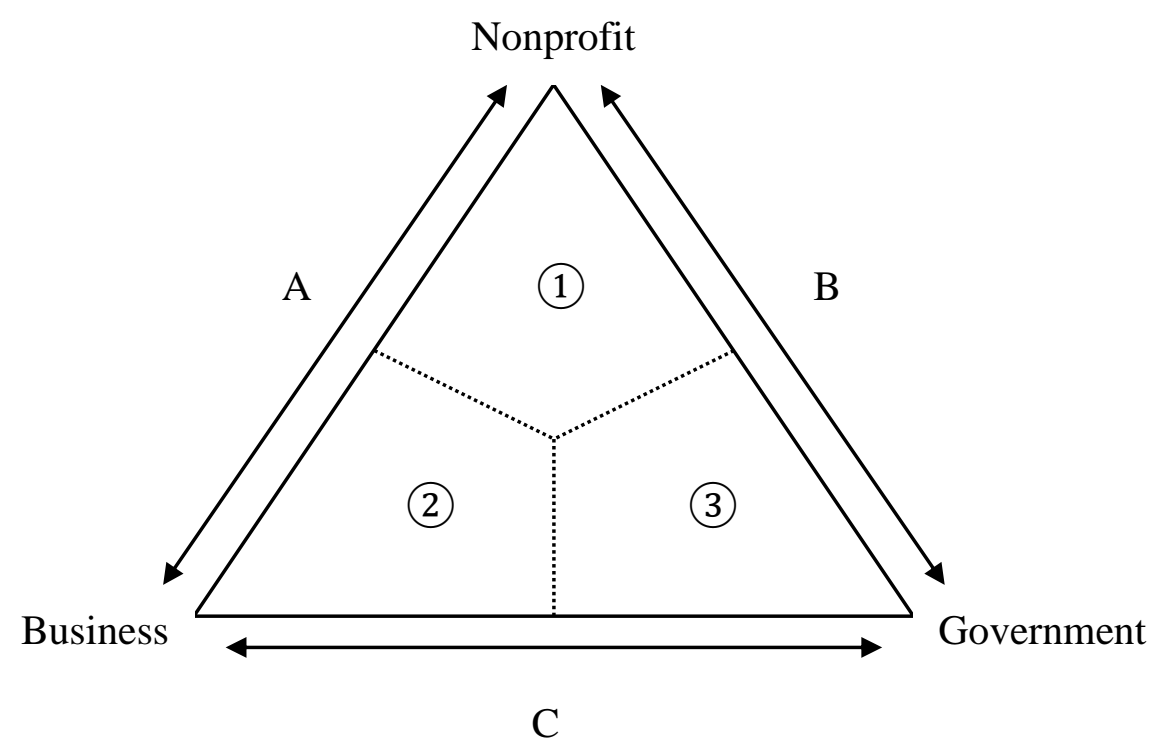

Fig. 1. The pillars of governance and their three main zones of influence. Spectrums A, $\mathrm{B}, \& \mathrm{C}$ refer to the relationships emphasized in existing literatures.

Source: Drawn by authors. 


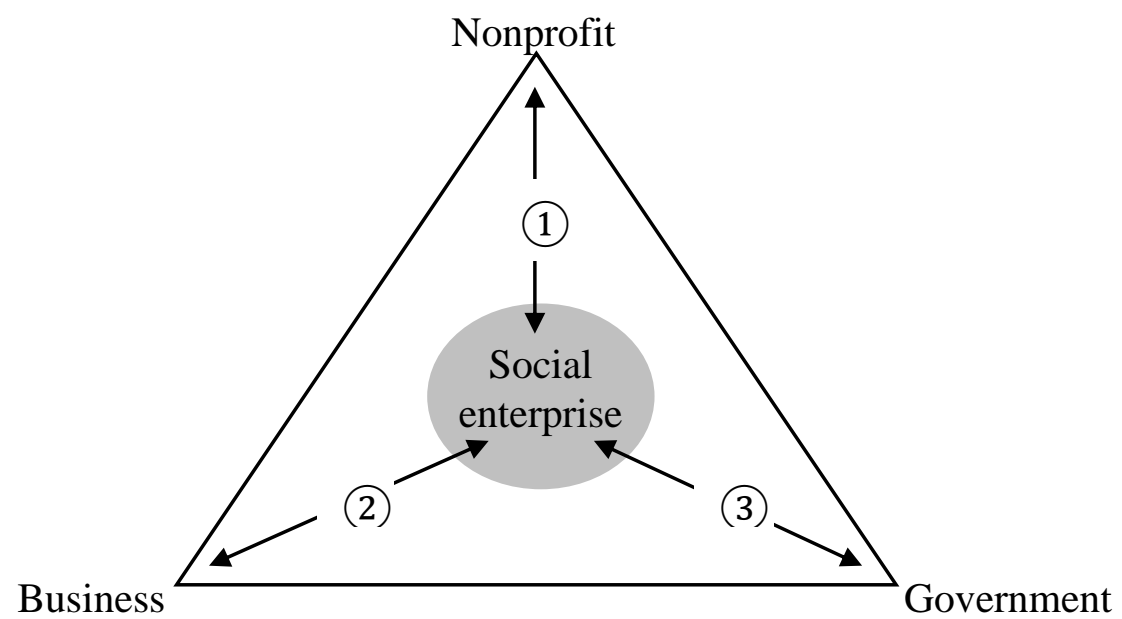

Fig. 2. Social enterprise as the institutional glue of governance networks. Spectrums 1,

$2, \& 3$ refer to social enterprise relations with nonprofits, businesses and government respectively.

Source: Drawn by authors. 